\title{
Nitrous Oxide Emission Rates over 10 Years in an Alpine Meadow on the Tibetan Plateau
}

\author{
Cao Yingfang ${ }^{1,2}$, Ke Xun ${ }^{1,2}$, Guo Xiaowei ${ }^{1}$, Cao Guangmin ${ }^{1}$, Du Yangong ${ }^{1 *}$ \\ ${ }^{1}$ Key Laboratory of Restoration and Ecology for Cold Regions in Qinghai, Northwest Institute of Plateau Biology, \\ Chinese Academy of Science, Xining, China \\ ${ }^{2}$ University of Chinese Academy of Science, Beijing, China
}

Received: 21 July 2017

Accepted: 3 September 2017

\begin{abstract}
The alpine grassland ecosystem covering about $85 \%$ of the Tibetan plateau is fragile and sensitive to natural and anthropogenic disturbances. However, it is unclear how nitrous oxide $\left(\mathrm{N}_{2} \mathrm{O}\right)$ has varied over the last 10 years. In order to accurately estimate the regional $\mathrm{N}_{2} \mathrm{O}$ emissions budget, the $\mathrm{N}_{2} \mathrm{O}$ levels, environmental factors, and biomass were investigated on a yearly, monthly, and seasonal basis from 2000 to 2014 in an alpine meadow. The results showed that there was an overall declining trend in emissions over 10 years, during which the two maximum emission rates were $64.8 \pm 11.1$ and $41.8 \pm 18.2 \mu \mathrm{g} \mathrm{m}^{-2} \mathrm{~h}^{-1}$ (in 2001 and 2006). The average $\mathrm{N}_{2} \mathrm{O}$ emissions rate was about $38.4 \pm 3.3 \mu \mathrm{g} \mathrm{m}^{-2} \mathrm{~h}^{-1}$. Pearson correlation demonstrated that soil and air temperature exerted a crucial influence on $\mathrm{N}_{2} \mathrm{O}$, followed by precipitation and aboveground biomass, but the effect of soil moisture at a depth of $10 \mathrm{~cm}$ was negative. Multiple linear regressions showed a good relationship between $\mathrm{N}_{2} \mathrm{O}$ and all environmental factors. Future scenarios of wetter and warmer weather would noticeably increase alpine meadow $\mathrm{N}_{2} \mathrm{O}$ emissions on the Tibetan Plateau.
\end{abstract}

Keywords: $\mathrm{N}_{2} \mathrm{O}$ emissions, alpine meadow, temperature, precipitation, aboveground biomass

\section{Introduction}

Nitrous oxide $\left(\mathrm{N}_{2} \mathrm{O}\right)$ is a powerful greenhouse gas with an atmospheric lifetime of more than 120 years. Its warming potential is reported to be 310 times higher than that of carbon dioxide [1]. Globally, $6 \%$ of all global warming is caused by $\mathrm{N}_{2} \mathrm{O}$ emissions, and those $\mathrm{N}_{2} \mathrm{O}$ levels in the atmosphere are increasing by $0.8 \mathrm{ppbv} \mathrm{a}^{-1}$ every year. The current level of $\mathrm{N}_{2} \mathrm{O}$ in the atmosphere is 324 ppbv. [2]. $\mathrm{N}_{2} \mathrm{O}$ production is largely attributed to terrestrial soil processes, which account for about $60-70 \%$

*e-mail: ygdu@nwipb.cas.cn of total $\mathrm{N}_{2} \mathrm{O}$ emissions [3]. Therefore, it is particularly necessary to focus on $\mathrm{N}_{2} \mathrm{O}$ production in terrestrial ecosystems.

The dominant ecosystem on the Tibetan Plateau is alpine meadow [4]. This unique ecosystem is characterized by a long, cold dormancy period and short, mild growing season [4]. Consequently, $\mathrm{N}_{2} \mathrm{O}$ emissions are estimated inaccurately under these arid and polar climatic conditions [5]. Massive efforts have been carried out to assess $\mathrm{N}_{2} \mathrm{O}$ emissions in agricultural management systems, but few studies have focused on alpine meadows [2-5]. There are inconsistent views about the variations in $\mathrm{N}_{2} \mathrm{O}$ emissions at diverse time scales (monthly, yearly, and between growing season and non-growing season). 
Previous studies have demonstrated that $\mathrm{N}_{2} \mathrm{O}$ emissions in the growing season are far higher than those during the non-growing season in alpine meadows [6]; however, the opposite trend was also reported [7]. There is a lack of long-term data on $\mathrm{N}_{2} \mathrm{O}$ emissions at different temporal scales.

$\mathrm{N}_{2} \mathrm{O}$ is released mostly from microorganisms involved in nitrification and denitrification, which depend on the soil physiochemical properties and external environmental conditions [8]. Although several studies have confirmed that the main factors affecting $\mathrm{N}_{2} \mathrm{O}$ emissions include precipitation, temperature, and biomass, many uncertainties still exist in these relationships, which are also affected by temporal changes. Hence, in order to accurately reveal temporal variations in $\mathrm{N}_{2} \mathrm{O}$ emissions and examine their effects on environmental factors in alpine meadows on the Tibetan Plateau, our research is based on long-term studies using different time scales can provide scientific proof to estimate emissions and further develop practical mitigation strategies in the future.

The aims of this study were as follows:

1) Investigate the trends in $\mathrm{N}_{2} \mathrm{O}$ emissions at different time scales, including yearly, monthly, and seasonal patterns.

2) Analyse the relationship between aboveground biomass and $\mathrm{N}_{2} \mathrm{O}$ emissions.

3) Identify the key environmental factors influencing $\mathrm{N}_{2} \mathrm{O}$ emissions and further predict variations in $\mathrm{N}_{2} \mathrm{O}$ emissions based on future climatic scenarios.

\section{Material and Methods}

\section{Study Site}

Our research was conducted in an alpine meadow on the Tibetan Plateau situated in the Haibei Alpine Meadow Experimental Ecosystem Research Station of the Chinese Academy of Sciences $\left(37^{\circ} 36^{\circ} \mathrm{N}, 101^{\circ} 12^{\circ} \mathrm{E}\right.$, $3,250 \mathrm{~m}$ above sea level). It is located in a valley encircled by the Qilian Mountains. The region has a typical plateau continental climate, with no significant distinction between the four seasons; instead, there are patterns of warmth and cold. The average annual air temperature is $-1.7^{\circ} \mathrm{C}$. The alpine meadow receives approximately $560 \mathrm{~mm}$ precipitation annually, and the maximum precipitation usually occurs in summer during the height of the growing season (the fifth to ninth month of the year), accounting for $80 \%$ of yearly rainfall. The clay loam soil is permanently wet and up to $65 \mathrm{~cm}$ thick. The total nutrient of soils defined as Mat Cry-gelic Cambisol is rich but barren of nutrients. The physical and chemical properties of the soil are shown in Table 1. The main plant communities in the region are Kobresia, Gentiana, Saxifraga, and Anemone; together, they have a coverage of nearly $75-80 \%$ [9].

\section{Sampling and Measurement}

$\mathrm{N}_{2} \mathrm{O}$ emission rates were measured using opaque static chambers. The stainless steel chambers consisted of two parts: a bottomless square box $\left(0.5 \times 0.5 \times 0.5 \mathrm{~m}^{3}\right)$ used to collect $\mathrm{N}_{2} \mathrm{O}$ gases, and a stainless steel base $\left(0.5 \times 0.5 \times 0.1 \mathrm{~m}^{3}\right)$ that was plugged into the meadow soil. Two electric fans were installed on top of the chamber to mix air, and a thermo-probe was used to monitor the internal temperature of the chamber during the sampling period. In addition, the external chamber was wrapped with white plastic foam and waterproof cloth, with the aim of avoiding increasing the interior temperature of the chamber caused by solar radiant heat during the sampling period.

The $\mathrm{N}_{2} \mathrm{O}$ samples were obtained roughly four times a month in the growing season (May to September) and twice a month in the non-growing season (October to April) from 2000 to 2014. During sampling, the opaque static chambers were completely sealed for at least $30 \mathrm{~min}$ between 09:00 and 10:00 local time, when $\mathrm{N}_{2} \mathrm{O}$ flux measurement is nearly identical to the diurnal mean. $\mathrm{N}_{2} \mathrm{O}$ samples were gathered once every $10 \mathrm{~min}$ using a three-way valve pumping samples into a $100 \mathrm{ml}$ syringe, and were sent for laboratory analysis within $48 \mathrm{~h}$. The $\mathrm{N}_{2} \mathrm{O}$ content of the samples was analyzed by a gas chromatograph (HP4890D, Agilent) equipped with an electron capture detector. The temperature of the detector and column oven were $330^{\circ} \mathrm{C}$ and $55^{\circ} \mathrm{C}$, respectively, and the instrument had an analysing accuracy of \pm 5 ppbv.

The aboveground biomass was measured by harvesting 10 squares $\left(0.25 \times 0.25 \mathrm{~m}^{2}\right)$ in the study plot once a month from April to October. The harvested biomass was dried at $65^{\circ} \mathrm{C}$ for $24 \mathrm{~h}$ and then weighed. Soil temperature was measured at depths of $5 \mathrm{~cm}$ and $10 \mathrm{~cm}$ using a digital thermometer (JM 624), while the $\mathrm{N}_{2} \mathrm{O}$ gas was collected. Air temperature and precipitation data were obtained from the meteorological station

Table 1. Basic soil properties of alpine meadow (means of three replicates are shown).

\begin{tabular}{|c|c|c|c|c|c|c|}
\hline Layer $(\mathrm{cm})$ & Organic carbon (\%) & Field capacity (\%) & $\mathrm{pH}$ & Bulk density $\left(\mathrm{g} \mathrm{cm}^{-3}\right)$ & $\mathrm{NO}_{3}^{-}\left(\mathrm{mg} \mathrm{kg}^{-1}\right)$ & $\mathrm{NH}_{4}^{+}\left(\mathrm{mg} \mathrm{kg}^{-1}\right)$ \\
\hline $0-10$ & 5.5 & 53.6 & 7.3 & 0.75 & 8.3 & 11.7 \\
\hline $10-20$ & 3.3 & ---- & 7.4 & 1.11 & 4.4 & 5.8 \\
\hline $20-30$ & 2.7 & 35.9 & ---- & 1.13 & 3.2 & 4.0 \\
\hline $30-40$ & 1.9 & ---- & ---- & 1.15 & 2.6 & 3.4 \\
\hline
\end{tabular}


at Haibei Station. The water content of the soil was calculated using the weighting method [10].

\section{Calculating $\mathrm{N}_{2} \mathrm{O}$ Emissions}

The rate of $\mathrm{N}_{2} \mathrm{O}$ emissions per hour is obtained using the linear slope of the gas concentration changing with time:

$$
F_{N_{2} O}=\rho \times \frac{V}{A} \times \frac{P}{P_{0}} \times \frac{T_{0}}{T} \times \frac{d C_{t}}{d t}
$$

...where $\mathrm{F}$ is $\mathrm{N}_{2} \mathrm{O}$ emissions per hour $\left(\mu \mathrm{g} \mathrm{m} \mathrm{m}^{-2} \mathrm{~h}^{-1}\right), \mathrm{V}$ is chamber volume $\left(\mathrm{cm}^{3}\right)$, A is bottom area of the chamber $\left(\mathrm{cm}^{3}\right), \mathrm{C}_{\mathrm{t}}$ is $\mathrm{N}_{2} \mathrm{O}$ concentration of the volume mixed at moment $\mathrm{t}\left(10^{-9} \mathrm{~L} /(\mathrm{L} \cdot \mathrm{min})\right), \mathrm{t}$ is time (min), $\rho$ is $\mathrm{N}_{2} \mathrm{O}$ emissions under standard conditions $\left(\mathrm{g} \mathrm{cm}^{-3}\right), \mathrm{T}_{0}$ and $\mathrm{P}_{0}$ are temperature $(\mathrm{K})$ and atmospheric pressure $(\mathrm{Pa})$ at sea level respectively, and $\mathrm{T}$ and $\mathrm{P}$ are temperature $(\mathrm{K})$ and atmospheric pressure $(\mathrm{Pa})$, respectively, during sampling in the chamber.

\section{Statistical Analyses}

Repeated measure analysis of variance (ANOVA) tests were used to explore whether the years and dates of sampling, and their interaction had an influence on $\mathrm{N}_{2} \mathrm{O}$ emissions. The relationship between $\mathrm{N}_{2} \mathrm{O}$ emissions and aboveground biomass was examined with simple linear regression analysis in SPSS (19.0). Multiple linear regression analyses was used to evaluate the effects of multiple variable environmental factors on $\mathrm{N}_{2} \mathrm{O}$ emissions, and Pearson correlation analyses were employed to explain the connections between $\mathrm{N}_{2} \mathrm{O}$ emissions and diverse factors such as precipitation, temperature (soil and air), soil moisture, and aboveground biomass.

\section{Results}

\section{$\mathrm{N}_{2} \mathrm{O}$ Emissions Dynamics at Different Time Scales}

The $\mathrm{N}_{2} \mathrm{O}$ emissions showed considerable year-to-year variation, and the average rate was $38.4 \pm 3.3 \mu \mathrm{g} \mathrm{m}^{-2} \mathrm{~h}^{-1}$ during 10 years. The lowest rate was $29.0 \pm 2.4 \mu \mathrm{g} \mathrm{m}^{-2} \mathrm{~h}^{-1}$ in 2009. There was an overall downward trend between 2000 and 2014. The first peak reached $64.8 \pm 11.1 \mu \mathrm{g} \mathrm{m}^{-2} \mathrm{~h}^{-1}$ in 2001. Then the $\mathrm{N}_{2} \mathrm{O}$ emissions dropped sharply to $37.4 \pm 6.1 \mu \mathrm{g} \mathrm{m}^{-2} \mathrm{~h}^{-1}$ in 2003 , and fluctuated slightly around $35.2 \pm 3.2 \mu \mathrm{g} \mathrm{m}^{-2} \mathrm{~h}^{-1}$ from 2003 to 2005 . The second peak was $41.8 \pm 18.2 \mu \mathrm{g} \mathrm{m}^{-2} \mathrm{~h}^{-1}$, after which emissions remained steady at about $31.6 \mu \mathrm{g} \mathrm{m}^{-2} \mathrm{~h}^{-1}$ in 2013 and 2014 (Fig. 1)

The $\mathrm{N}_{2} \mathrm{O}$ emissions indicated a clear seasonal pattern, with an average emission rate of $49.9 \pm 3.5 \mu \mathrm{g} \mathrm{m}^{-2} \mathrm{~h}^{-1}$ in the growing season, which was significantly higher than $\left(27.0 \pm 4.9 \mu \mathrm{g} \mathrm{m}^{-2} \mathrm{~h}^{-1}\right)$ in the dormant season $(\mathrm{p}<0.05) . \mathrm{N}_{2} \mathrm{O}$



Fig. 1. $\mathrm{N}_{2} \mathrm{O}$ emission dynamics in growing and dormant seasons, yearly scales (data were not measured in 2002, 2007, 2008, 2011, and 2012).

emissions showed enormous fluctuation in the growing season and presented a general declining trend in the nongrowing season during 10 years (Fig. 1).

Monthly $\mathrm{N}_{2} \mathrm{O}$ emissions fluxes showed obvious pulse variations (Fig. 2). The first peak appeared in March, reaching $32.8 \pm 10.7 \mu \mathrm{g} \mathrm{m}^{-2} \mathrm{~h}^{-1}$. The magnitudes of the $\mathrm{N}_{2} \mathrm{O}$ fluxes varied dramatically, and the second peak reached $73.7 \pm 16.3 \mu \mathrm{g} \mathrm{m}^{-2} \mathrm{~h}^{-1}$ in August. The lowest value was observed in February (Fig. 2).

Repeated measures of ANOVA showed a significant difference among inter-year $\mathrm{N}_{2} \mathrm{O}$ emissions, different sampling dates, and their interactions (Table 2). In addition, the effect of sampling dates on emission rates was higher than on the yearly scale.

\section{Effects of Aboveground Biomass and Environmental Factors on $\mathrm{N}_{2} \mathrm{O}$ Emissions}

It was revealed that aboveground biomass significantly affects $\mathrm{N}_{2} \mathrm{O}$ emissions in the growing season $\left(\mathrm{R}^{2}=0.45\right.$, $\mathrm{p}<0.05$; Fig. 3). This study demonstrated that precipitation and $\mathrm{N}_{2} \mathrm{O}$ emissions showed a weak positive

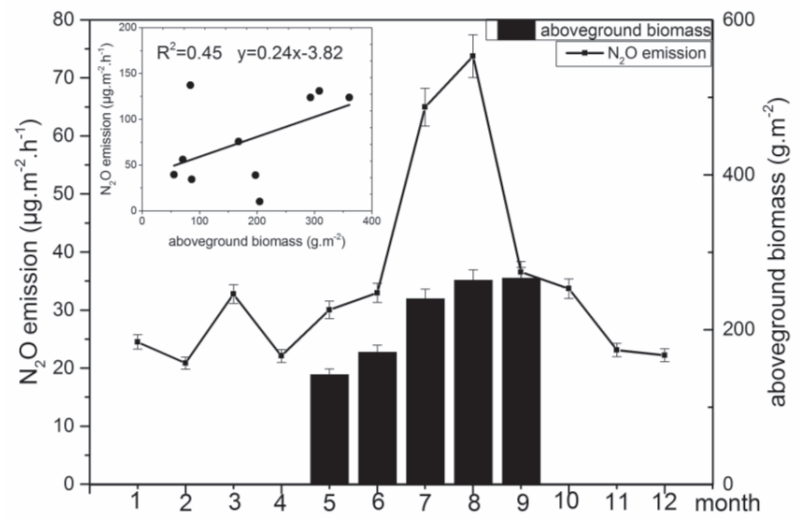

Fig. 2. $\mathrm{N}_{2} \mathrm{O}$ monthly variation and aboveground variation during growing season and their correlation. 
Table 2. Effect of sampling time on soil $\mathrm{N}_{2} \mathrm{O}$ emissions of an alpine meadow.

\begin{tabular}{|c|c|c|c|}
\hline Items & $\mathrm{d}_{\mathrm{f}}$ & $\mathrm{F}$ & $\mathrm{P}$ \\
\hline Year & 9 & 23.12 & $0.01^{* *}$ \\
\hline Date & 29 & 139.49 & $0.000^{* *}$ \\
\hline Year $\times$ date & 261 & 65.42 & $0.002^{* *}$ \\
\hline
\end{tabular}

correlation $(\mathrm{R}=0.1$; Fig. 3). However, soil moisture at $10 \mathrm{~cm}$ soil made a negligible contribution to $\mathrm{N}_{2} \mathrm{O}$ emissions $(\mathrm{R}=0.3$; Fig. 3). Soil temperature at $5 \mathrm{~cm}$ and air temperature were positively correlated with $\mathrm{N}_{2} \mathrm{O}$ emissions ( $\mathrm{R}=0.51, \mathrm{R}=0.48$ ). Compared to precipitation and soil moisture, $\mathrm{N}_{2} \mathrm{O}$ emissions rates were controlled to a greater extent by the soil temperature at $5 \mathrm{~cm}$ and air temperature. Environmental factors and biomass $\left(\mathrm{R}^{2}=0.43\right.$, Table 3$)$ were also well described by multiple linear regression equations.

\section{Discussion}

Previous studies have revealed that grasslands were sources of $\mathrm{N}_{2} \mathrm{O}$ emissions [11]. However, the differences were significant among different studies performed on the Haibei Alpine Meadow; emission rates varied from 4.1 to $54 \mu \mathrm{g} \mathrm{m}^{-2} \mathrm{~h}^{-1}[5,9,12]$. Here, we calculated values for alpine meadows more accurately using long-term field measurements.

This study also describes in detail the declining trend in $\mathrm{N}_{2} \mathrm{O}$ emission rates, with two peaks during 10 years. This phenomenon was closely related to environmental factors [13]. Temperatures impacted microbe activity as well as $\mathrm{N}_{2} \mathrm{O}$ emission diffusion; warming could
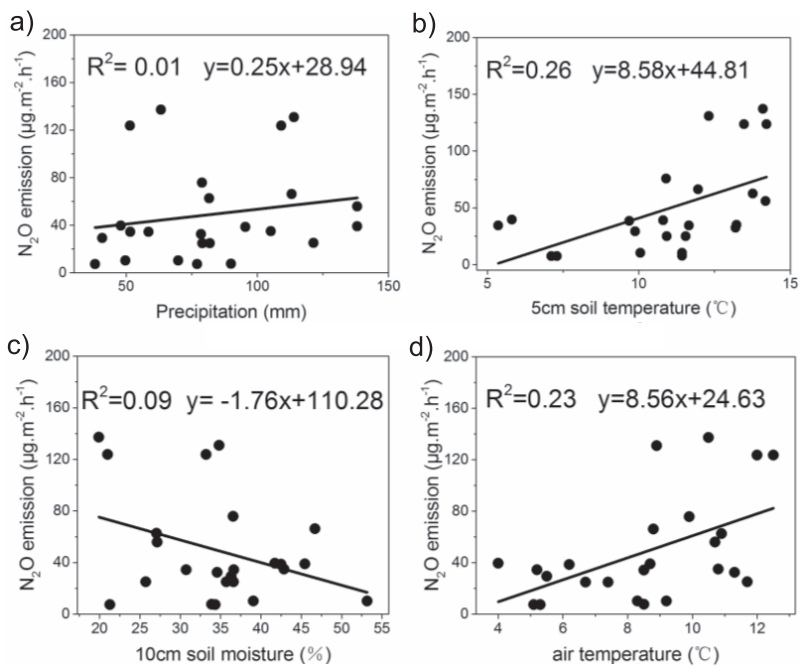

Fig. 3. Linear fitting between environmental factors (precipitation, $5 \mathrm{~cm}$ and $10 \mathrm{~cm}$ soil moisture, and air temperature) and $\mathrm{N}_{2} \mathrm{O}$ emissions.
Table 3. Multiple liner regression analysis equation between $\mathrm{N}_{2} \mathrm{O}$ emissions and environmental variables measured in the alpine meadow.

\begin{tabular}{|c|c|c|c|}
\hline Equation & $\mathrm{R}^{2}$ & $\mathrm{~F}$ & $\mathrm{P}$ \\
\hline $\begin{array}{c}\mathrm{Y}=-0.07 \mathrm{P}-1.47 \mathrm{Sm}+1.75 \mathrm{Ta} \\
+5.99 \mathrm{Ts}+0.23 \mathrm{~B}+35.46\end{array}$ & 0.43 & 1.71 & 0.19 \\
\hline
\end{tabular}

$\mathrm{P}$ means precipitation, $\mathrm{Sm}$ means soil moisture at $10 \mathrm{~cm}$ depth, Ta and Ts represent air temperature and $5 \mathrm{~cm}$ soil temperature, and $\mathrm{B}$ means aboveground plant biomass.

trigger soil nitrification and lead to the release of a large amount of $\mathrm{N}_{2} \mathrm{O}$ [14]. $\mathrm{N}_{2} \mathrm{O}$ emissions were mainly caused by nitrification in alpine meadows [3] and temperate meadows [15]. Nitrification occurs between $15^{\circ} \mathrm{C}$ and $30^{\circ} \mathrm{C}$, but it can be inhibited at temperatures below $15^{\circ} \mathrm{C}$ or over $40^{\circ} \mathrm{C}$ [16-17]. The $\mathrm{N}_{2} \mathrm{O}$ emission peaks occurred in 2001 and 2006, which were also warm years. For the last 10 years, global warming tendencies were delayed on the Tibetan Plateau [18]. Thus, the majority of $\mathrm{N}_{2} \mathrm{O}$ emissions were trapped in soil, and little could be released to the atmosphere during cold years [19].

On the other hand, precipitation gradually increased during the last 10 years [18]. Rainfall affects the biological process of $\mathrm{N}_{2} \mathrm{O}$ production by changing the oxygen content in the soil pores [20]. $\mathrm{N}_{2} \mathrm{O}$ is reduced to $\mathrm{N}_{2}$ by denitrification when the soil water content is high and soil oxygen is low. It also has been reported that humid soil is conducive to the accumulation of soil organic matter, thus increasing the available supply of substrates for microbes, further stimulating $\mathrm{N}_{2} \mathrm{O}$ emissions [21].

This study revealed that aboveground biomass played a crucial role in $\mathrm{N}_{2} \mathrm{O}$ fluxes in alpine meadows. A similar result was also reported for salt marshes and wheat fields [22] because the number of denitrifying bacteria and nitrification intensity were affected by plant communities, plant litter, and root exudates as a consequence of changing the soil $\mathrm{N}_{2} \mathrm{O}$ emission fluxes [23-24]. Plant aerenchymae would also play an important role in gas transportation, leading to increased $\mathrm{N}_{2} \mathrm{O}$ emissions from the roots to the air [25]. In addition, plant root respiration accelerates oxygen consumption and facilitates the creation of anaerobic conditions during the growing season, causing further $\mathrm{N}_{2} \mathrm{O}$ emissions by enhancing denitrification $[12$, 26-27].

According to Coupled Model Intercomparison Project Phase5 (CMIP5), the Tibetan plateau experiences a wetter climate and temperatures will continue to rise at the rate of $0.26^{\circ} \mathrm{C}$ every decade in the next 50 years [28]. $\mathrm{N}_{2} \mathrm{O}$ will increase by about $8 \%$ against the global background of a warmer and wetter scenario, because the rate of $\mathrm{N}$ cycle would increase under future climatic conditions [29]. Our research showed that $\mathrm{N}_{2} \mathrm{O}$ emissions were controlled by temperature; the $\mathrm{Q}_{10}$ value was 2.21 , and precipitation levels exerted a negligible influence. Therefore, we predict a steady increase in $\mathrm{N}_{2} \mathrm{O}$ emissions in the alpine meadows of the Tibetan plateau, based on future climatic warming and wetting conditions. 


\section{Conclusions}

There was an overall downward trend in $\mathrm{N}_{2} \mathrm{O}$ emissions over 10 years, during which the average emission rate was about $38.4 \pm 3.3 \mu \mathrm{g} \mathrm{m}^{-2} \mathrm{~h}^{-1}$. And $\mathrm{N}_{2} \mathrm{O}$ emissions in the growing season were significantly higher than in the dormant season. Besides, temperature (soil and air) produced a critical impact on $\mathrm{N}_{2} \mathrm{O}$, followed by precipitation and aboveground biomass, but the effect of soil moisture at a depth of $10 \mathrm{~cm}$ was negative. Therefore, it is predicted that future scenarios of wetter and warmer weather would significantly increase alpine meadow $\mathrm{N}_{2} \mathrm{O}$ emissions on the Tibetan Plateau.

\section{Acknowledgements}

This work was supported by the National Natural Science Foundation of China (31470530,31770532 and 31400483), and Qinghai innovation platform construc-tion project (2017-ZJ-Y20), and National Key Fundamental Plan for Soil System Carbon Dymanic and Mechamism Response for Global Climate Change (2014CB954002).

\section{Reference}

1. BHATAIA A., SASMAL S., JAIN N., PATHAAK H., KUMAR R., SINGH A. Mitigating nitrous oxide emission from soil under conventional and no-tillage in wheat using nitrification inhibitors. Agr. Ecosyst. Environ. 136, 247, 2010.

2. ZHANG Y.J., NIU H.S., WANG S.P., Xu, K., WANG R. Application of the DNDC model to estimate $\mathrm{N}_{2} \mathrm{O}$ emissions under different types of irrigation in vineyards in Ningxia, China. Agr. Water Manage. 163, 295, 2016.

3. DU Y.G., GUO X.W., CAO G.M., WANG B., PAN G.Y., LIU D.L. Simulation and prediction of nitrous oxide emission by the water and nitrogen management model on the Tibetan plateau. Biochem. Syst. Ecol. 65, 49, 2016.

4. ZHANG W., LIU C.Y., ZHENG X.H., FU Y.F, HU X.X., CAO G.M. BUTTERBACH-BAHL K. The increasing distribution area of zokor mounds weaken greenhouse gas uptakes by alpine meadows in the Qinghai-Tibetan Plateau. Soil Biol. Biochem. 71, 105, 2014.

5. HU Y.G, CHANG X.F, LIN X.W., WANG Y.F., WANG S.P., DUAN J.C., ZHANG Z.H., YANG X.X., LUO C.Y., XU G.P., ZHAO X.Q. Effects of warming and grazing on $\mathrm{N}_{2} \mathrm{O}$ fluxes in an alpine meadow ecosystem on the Tibetan plateau. Soil Biology and Biochemistry, 42 (6), 944, 2010.

6. LI Y.Y., DONG S.K., LIU S.L., ZHOU H.K., GAO Q.Z., CAO G.M., WANG X.X., SU X.K., ZHANG Y., TANG L., ZHANG H.D., WU X.Y. Seasonal changes of $\mathrm{CO}_{2}, \mathrm{CH}_{4}$ and $\mathrm{N}_{2} \mathrm{O}$ fluxes in different types of alpine grassland in the Qinghai-Tibetan Plateau of China. Soil Biol. Biochem. 80, 306, 2015.

7. WANG G.S.,WANG X.F., REN F., ZHANG Z.H., HE J.S. Non-growth season's gases emission and its yearly contribution from alpine meadow on Tibetan Plateau of China. Chinese. J. Ecol. 32, 1994, 2013.

8. HEROLD M.B., BAGGS E.M., DANIELL T.J. Fungal and bacterial denitrification are differently affected by long- term $\mathrm{pH}$ amendment and cultivation of arable soil. Soil Biol. Biochem. 54, 25, 2012.

9. DU Y.G., CUI Y.G., Xu X.L., LIANG D., LONG R.J., CAO G.M. Nitrous oxide emissions from two alpine meadows in the Qinghai-Tibetan Plateau. Plant and Soil, 311, 245, 2008.

10. LI W.X., CUI Y.Y. Research progress of soil moisture and its measurement. Jiangsu Agri. Sci. 42, 335, 2014.

11. WILliAMS PI, DING Li., COWARD P.A. Temporal variations in nitrous oxide fluxes from urine-affected grassland. Soil Biol. Biochem. 31, 779, 1999.

12. TOAL C.Y., KILLHAM M.E., HARG A.A. A review of rhizophere carbon flow modelling. Plant Soil 222, 263, 2000.

13. LIU X.R., DONG Y.S., QI Y.C., LI S.G. N2O fluxes from the native and grazed semi-arid steppes and their driving factors in Inner Mongolia, China. Nutr. Cycl. Agroecosys. 86, 231, 2010.

14. HOLST J., LIU C., BRUGGERMANN N., BUTTEBACHBAHL K., ZHENG X., WANG Y., HAN S., YAO Z., YUE J., HAN X. Microbial N Turnover and $\mathrm{N}-\mathrm{Oxide}\left(\mathrm{N}_{2} \mathrm{O} / \mathrm{NO} /\right.$ $\mathrm{NO}_{2}$ ) Fluxes in Semi-arid Grassland of Inner Mongolia. Ecosystems, 10 (4), 623, 2007.

15. RUI D. The processes of $\mathrm{N}_{2} \mathrm{O}$ production in temperate meadow grassland soils. Ecol. Sci. 25, 202, 2006.

16. Zhao M.M, ZHANG W.Z., PEI Y. Research advances on $\mathrm{N}_{2} \mathrm{O}$ emission in agricultural soil. Crops, 4, 25, 2013.

17. LIU X.C., QI Y.C., DONG Y.S., PENG Q., HE Y.T., SUN L.J., JIA J.Q., CAO C.C. Response of soil $\mathrm{N}_{2} \mathrm{O}$ emissions to precipitation pulses under different nitrogen availabilities in a semiarid temperate steppe of Inner Mongolia, China. Journal of Arid Land. 6 (4), 410, 2013.

18. PIAO S.L., CIAIS P., HUANG Y., SHEN Z., PENG S., LI J., ZHOU L., LIU H., MA Y., DING Y. The impacts of climate change on water resources and agriculture in China. Nature 467, 43, 2010.

19. ARACHK.A., RICHTON J.R., LI I.J.,HU S. Nitrous oxide production and denitrification in Scottish arable soils. Soil Sci. 42, 351, 1991.

20. JIANG C.M., YU G.R., FANG H.J., CAO G.M., Li Y.N. Short-term effect of increasing nitrogen deposition on $\mathrm{CO}_{2}$, $\mathrm{CH}_{4}$ and $\mathrm{N}_{2} \mathrm{O}$ fluxes in an alpine meadow on the QinghaiTibetan Plateau, China. Atmos. Environ. 44, 2920, 2010.

21. CHEN S.T., HUANG Y., ZOU J.W. Relationship between nitrous oxide emission and winter wheat production. Biol. Fertility Soils 44, 985, 2008.

22. HIROTA M., SENGA Y., SEIKE Y., NOHARA S., KUNII $H$. Fluxes of carbon dioxide, methane and nitrous oxide in two contrastive fringing zones of coastal lagoon, Lake Nakaumi, Japan. Chemosphere. 68, 597, 2007.

23. CAI Z.C., ZHAO W. Effects of land use types on nitrification in humid subtropical soils of China. Acta Ecol. Sin. 46, 795, 2009.

24. DANNENBERG S., CONRAD R. Effect of rice plants on methane productionand rhizospheric metabolism in paddy soil. Biogeochemistry 45, 53, 1999.

25. JORGENSEN C.J., STRUWE S., ELBERLING B. Temporal trends in $\mathrm{N}_{2} \mathrm{O}$ flux dynamics in a Danish wetland - effects of plant-mediated gas transport of $\mathrm{N}_{2} \mathrm{O}$ and $\mathrm{O}_{2}$ following changes in water level and soil mineral-Navavailability. Global Change Biol. 18, 210, 2012.

26. SUN H.Y., ZHANG C.B., SONG C.C., CHANG S.X., GU B.J., CHEN Z.X., PENG C.H., CHANG J., GE Y. The effects of plant diversity on nitrous oxide emissions in hydroponic microcosms. Atmos. Environ. 77, 544, 2013.

27. DU Y.G., CAO G.M., DENG Y.C., SUN G.C., CUI X.Y. Contribution of the vegetation layers in the nitrous oxide 
emission from alpine Kobresia humilis Serg. meadow ecosystem on the Tibetan Plateau. Pol. J. Ecol. 58, 115, 2010.

28. HU Q., JIANG D, B., FAN G.Z. Climate change projection on the Tibetan Plateau: results of CMIP5 models. Chinese J. Atmos. Sci. 39, 42, 2015.
29. KEITH A. S. The potential for feedback effects induced by global warming on emission of nitrous oxide by soils. Global Change Biol. 3, 327, 1997. 